\title{
Larval endoparasitoids (Hymenoptera) of frugivorous flies (Diptera, Tephritoidea) reared from fruits of the cerrado of the State of Mato Grosso do Sul , Brazil
}

\author{
Manoel A. Uchôa-Fernandes ${ }^{1}$ \\ Rosa M. da S. Molina ${ }^{1,2}$ \\ Isaias de Oliveira ${ }^{1,2}$ \\ Roberto A. Zucchi ${ }^{3}$ \\ Nelson A. Canal ${ }^{4}$ \\ Norma B. Díaz ${ }^{5}$
}

\begin{abstract}
Aвstract. This paper presents a five years survey of endoparasitoids obtained from the larvae of frugivorous Tephritidae and Lonchaeidae flies. The insects were reared from cultivated and wild fruits collected in areas of the cerrado in the State of Mato Grosso do Sul, Brazil. The flies obtained from 14 host fruit species were eight Anastrepha species, Ceratitis capitata (Wiedemann, 1824) (Tephritidae); Dasiops sp. and Neosilba spp. (Lonchaeidae). Eleven parasitoid species were collected: Braconidae - Asobara anastrephae (Muesebek, 1958), Doryctobracon areolatus (Szépligeti, 1911), D. fluminensis (Costa Lima, 1938), Opius bellus Gahan, 1930 and Utetes anastrephae (Viereck, 1913); Figitidae - Aganaspis nordlanderi Wharton, 1998, Lopheucoila anastrephae (Rhower, 1919), Odontosema anastrephae (Borgmeier, 1935) and Trybliographa infuscata Gallardo, Díaz \& Uchôa-Fernandes, 2000 and, Pteromalidae - Spalangia gemina Boucek, 1963 and S. endius Walker, 1839. In all cases only one parasitoid emerged per puparium. D. areolatus was the most abundant and frequent parasitoid of fruit fly species, as was L. anastrephae in Neosilba spp. larvae. This is the first record of $A$. nordlanderi in the midwestern Brazilian region.
\end{abstract}

KEYWORDS. Biocontrol; fruit fly; Lonchaeids; parasitoids.

\section{INTRODUCTION}

The flies of the Tephritidae and Lonchaeidae families (Tephritoidea) are the most important insect pests of fruit and vegetables grown in the world, specially in the Neotropical region. The control of such flies by parasitoids has been considered an important component of integrated pest management (IPM) and also one of the safest methods for man and environment. The biological control program of fruit flies around the world have used exotic parasitoids (HERNÁNDEZOrtiz et al. 1994; SALLES 1996) which, besides enduring environmental adaptation difficulties (usually being species from another country or continent), may cause contrary effects upon the native parasitoids. More attention must be given to the use of native parasitoids in such program, mainly when they are abundant and have a performance similar or only somewhat inferior to that found in effective exotic species.

There is little research on native parasitoids of frugivorous tephritoids in Brazil (Leonel Jr. et al. 1995, 1996; CANAL et al. 1995; Salles 1996; Aguiar-Menezes \& Menezes 1997), in spite of their enormous potential as biological control agents of fruit flies (LóPEZ et al. 1999) and frugivorous lonchaeids. The aim of this study was to survey native parasitoids of fruit flies [Anastrepha spp., Ceratitis capitata (Wied.)] and frugivorous lonchaeids (Neosilba spp. and Dasiops sp.) obtained in the laboratory in cultivated and wild fruit species from cerrado

\footnotetext{
1. Laboratório de Insetos Frugívoros, Departamento de Ciências Biológicas, Universidade Federal de Mato Grosso do Sul. Caixa Postal 241, 79804-970 Dourados-MS, Brazil. E-mail:uchoa@ceud.ufms.br

2. Trainee biologist.

3. Departamento de Entomologia, Fitopatologia e Zoologia Agrícola, ESALQ-USP. Caixa Postal 9, $13418-900$ Piracicaba-SP, Brazil.

E-mail:razucchi@esalq.usp.br

4. Facultad de Agronomia, Universidad del Tolima. Apartado Aéreo 546, Ibagué - Tolima, Colômbia.

5. Departamento Científico de Entomología, Museo de La Plata. Passeo del Bosque, 1900 La Plata, Argentina.
} 
vegetation of the State of Mato Grosso do Sul (midwestern Brazil).

\section{MATERIALAND METHODS}

The fruits were collected from January 1993 to March 1997, from "Cerrado" vegetation of Anastácio (20 31' 36" S / 55 50'

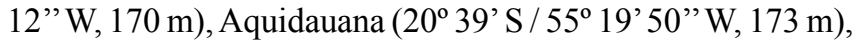

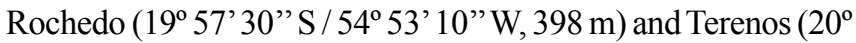
$26^{\prime} 12^{\prime \prime} \mathrm{S} / 54^{\circ} 04^{\prime} 54^{\prime \prime} \mathrm{W}, 308 \mathrm{~m}$ ) municipalities and brought to the laboratory. The parasitoids were recovered from frugivorous larvae of the families Tephritidae and Lonchaeidae. Each sample was placed in a plastic container, from which the ${ }^{\text {rd }}$ instar larvae exited and fell into plastic trays with water. Larvae were recovered every $12 \mathrm{~h}$ by pouring the material through a sieve with a mesh of $1 \mathrm{~mm}$ diameter, so tephritids and lonchaeids maggots were kept separate in different containers, in order to pupate and allow the emergence of flies or their parasitoids (UCHÔA-FernANDES \& ZucChi 1999). Only Spondias lutea L., 1758 (Anacardiaceae) and Terminalia catappa L., 1758 (Combretaceae) data, from fruit collected in 1993, were obtained by the usual methodology that consisted of placing fruits over trays containing a fine layer of sterilized sand. In this case, the puparia were recovered through sand sifting.

The viability of $3^{\text {rd }}$-instar larvae (L3) and the percentage of emergence of frugivorous flies were calculated according to the following formula, adapted from NASCIMENTO et al. (1984):

$\% \mathrm{~V} . \mathrm{L} 3=$ Number of emerged flies $\mathrm{x} 100$

Total No. of L3 - No. of emerged parasitoids

$\%$ V.L3 (Percentage of the viability of third instar larvae).

The combined larval parasitism rate (total parasitism) by hymenopterans was calculated using the formula:

$$
\begin{gathered}
\% \text { C.P. }=\text { N.R.P. } \times 100 \\
\text { N.L3 }
\end{gathered}
$$

$\%$ C.P $=$ The percentage of total parasitism rate;

N.R.P. $=$ Number of recovered parasitoids;

$\mathrm{N}$. L3 $=$ The number of $3^{\text {rd }}$-instar larvae of frugivorous flies.

The voucher specimens of tephritids, frugivorous lonchaeids and their parasitoids were deposited in the Coleção Zoológica, Universidade Federal de Mato Grosso do Sul, Campo Grande (ZUFMS) and Departamento de Entomologia, Fitopatologia e Zoologia Agrícola, Escola Superior de Agricultura "Luiz de Queiroz", Universidade de São Paulo, Piracicaba (ESALQ). The herborized samples of the host plants were deposited in the Herbário Central, Universidade Federal de Mato Grosso do Sul, Campo Grande and in the Coleção de Botânica, Departamento de Biologia, Universidade de São Paulo, São Paulo.

\section{RESULTSAND DISCUSSION}

From January 1993 to March 1997, 283 samples were collected, totaling $648.66 \mathrm{~kg}$ of biomass and 20,166 fruits of 14 plant species; 193 corresponded to Citrus spp. (Rutaceae) and 90 to other fruits. Some 11,298 mature larvae of Tephritidae were obtained, emerging as: 4,814 adults of Anastrepha spp., 2,637 Ceratitis capitata, 225 braconids and 23 pteromalids. Also, 11,246 larvae of Lonchaeidae were recovered, giving one adult of Dasiops sp., 7,677 Neosilba spp. and 279 Eucoilinae (Figitidae) parasitoids (Table I). In all cases only one parasitoid emerged per puparium.

\section{Parasitoid species composition (Table I)}

\section{Braconidae}

Asobara anastrephae (Muesebek) (5 specimens), Doryctobracon areolatus (Szépligeti) (166 specimens), D. fluminensis (Costa Lima) (12 specimens), Opius bellus Gahan (17 specimens), Utetes anastrephae (Viereck) (23 specimens) and two unidentified braconids were obtained. All recovered braconids were associated with Tephritidae larvae (Anastrepha spp. and C. capitata). Generally, the braconid species found in this survey correspond to those already registered in other Brazilian regions (CANAL et al. 1995; LeONEL Jr et al. 1995, 1996; Salles 1996; Aguiar-Menezes \& Menezes 1997). However, $D$. fluminensis which after its description by CosTA Lima (1938) has not been collected since, was found in 1993 in Fazenda Ranchinho, municipality of Rochedo, Mato Grosso do Sul. In this survey, $D$. fluminensis was obtained from larvae feeding on cassava fruits, Manihot esculenta Crantz, 1766 (Euphorbiaceae), probably parasiting A. montei Costa Lima, 1934.

Doryctobracon areolatus was the most abundant braconid, achieving $31.38 \%$ of the parasitoid adults and $74.67 \%$ of the braconids (Table I). That species shows a worldwide distribution and has been considered an important native parasitoid species attacking the genus Anastrepha in neotropical countries. Surveys carried out in Brazil and in other countries have shown that $D$. areolatus is the most dominant, frequent and abundant species among the parasitoids of fruit flies (JiRÓN \& MEXZON 1989; HernÁNDEZ-Ortiz et al. 1994; OvruSKI \& Fidalgo 1994; Canal et al. 1995; Leonel Jr. et al. 1995, 1996; Salles 1996; Aguiar-Menezes \& Menezes 1997; López et al. 1999).

\section{Figitidae}

Four especies in four genera of Eucoilinae were found in the present study: Aganaspis nordlanderi Wharton (16 specimens), Lopheucoila anastrephae (Rhower) (230 specimens), Odontosema anastrephae (Borgmeier) (6 specimens), Trybliographa infuscata Gallardo, Díaz \& UchôaFernandes (24 specimens) and three unidentified specimens. This is the first record of $A$. nordlanderi in the midwestern Brazilian region. T. infuscata was described from specimes 


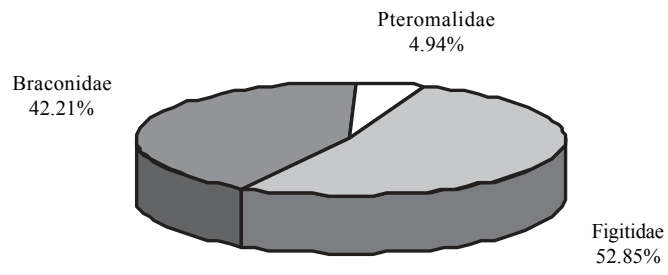

Fig. 1. Families of hymenopteran parasitoids $(n=527)$ reared from frugivorous larvae in 14 host fruit species from the cerrado, Mato Grosso do Sul, Brazil (January 1993 to March 1997).

parasitising larvae of Neosilba sp. infesting oranges in Anastácio, Terenos, and from Caryocar brasiliense Camb. 1828, fruits ("pequi") (Caryocaraceae), collected in Aquidauana (GALlARDO et al. 2000). The adults of Trybliographa are larval endoparasitoids that emerged from Neosilba spp. puparia.

All eucoilines were associated with the Lonchaeidae larvae of the genus Neosilba. These solitary endoparasitoids lay their eggs in the larval stages of Cyclorrhaphous Diptera and emerge as adults from the puparium of their hosts. They are important natural enemies of phytophagous dipterans (WHARTON et al. 1998). Two species of Eucoilinae have been used as biological control agents of some economically important fruit flies: Aganaspis daci (Weld, 1951) (oriental species) and $A$. pelleranoi (Brèthes, 1924) (neotropical species) and, this latter species has been mass reared and released in orchards in Argentina and Mexico for the control of tephritid pests (WHARTON et al. 1998).

The eucoilines made up almost $53 \%$ of the total of the recovered parasitoids (Fig. 1). L. anastrephae was the species with the highest abundance and the most frequent in the samples, totaling $82.44 \%$ of the eucoilines collected (Fig. 2). This parasitoid species has high potential as a biological control agent for lonchaeid pests of the genus Neosilba, specially in Citrus orchards in Mato Grosso do Sul, where the parasitism of this species is constant, in spite of the frequent insecticide sprays.

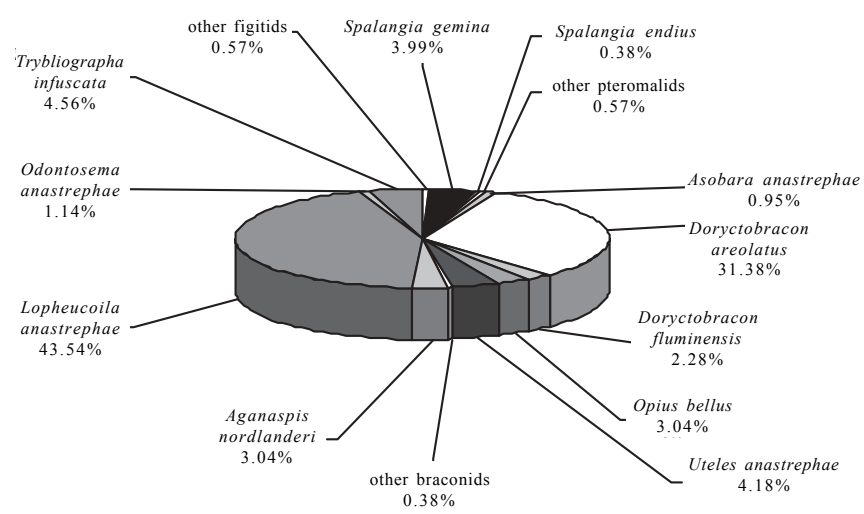

Fig. 2. Percent of the species of hymenopterans $(n=527)$ parasiting larvae of frugivorous flies from 14 host fruit species from the cerrado, Mato Grosso do Sul, Brazil (January 1993 to March 1997).
All the eucoilines registered in this study were associated with lonchaeids (Table I). Based on a survey in the region of Pelotas (Southern Brazil) related to native parasitoids of $A$. fraterculus, Odontosema sp. was listed among the parasitoids complex of the South American fruit fly (SALLES 1996). Although considering that the author applied the traditional methodology of fruit fly collecting, which kept all the insects together in the same container, probably Odontosema was parasiting Lonchaeidae larvae. As WHARTON et al. (1998) pointed out, if the larvae or pupae of frugivorous insects were kept together in the same rearing recipient until the emergence of adults, it will be possible to make a wrong association among the hosts and parasitoids.

In this survey, $O$. anastrephae emerged from larvae of Neosilba spp. infesting fruits of "pequi" (C. brasiliense). Although the eucoilines have been characterized as larval endoparasitoids of lonchaeids, other authors have found species of Odontosema and Aganaspis parasiting C. capitata and Anastrepha spp. larvae, as well as lonchaeids (WhARTON et al. 1981, 1998). WHARTON et al. (1998) pointed out that the records of the genus Lopheucoila and Trybliographa attacking tephritids in the New World need confirmation. In fact, our results show that $L$. anastrephae and $T$. infuscata were recovered only from Neosilba larvae (Lonchaeidae). Neverthless, in contrast to the results obtained by WHARTON $e t$ al. (1998), who found a preference of Odontosema for tephritids, with only $2 \%$ of this species being recovered from frugivorous lonchaeids, we found that $O$. anastrephae was associated only with Neosilba spp. larvae. According to LóPEZ et al. (1999), in Mexico, A. pelleranoi and $O$. anastrephae were obtained from pupae of Anastrepha spp. in guavas. Although these authors have associated those parasitoids with Anastrepha species, they did not identify previously the larvae that exited from fruits. So, it is possible that that parasitoid, in fact, was parasitising lonchaeids, which also infest guavas.

\section{Pteromalidae}

Two species were reared, Spalangia gemina Boucek (21 specimens) and $S$. endius Walker (2 specimens). The pteromalids seem to be associated with pupae of Tephritidae. The species of the genus Spalangia attack exclusively puparia of dipterans (V. A. Costa, personal communication). In this study, probably the parasitism occurred in the puparia collected in the field, because fruits ( $S$. lutea and $T$. catappa) from which these parasitoids emerged, were kept when traditional methodology was still being used ( in 1993), i.e., all larvae were kept together in the same container.

The average of parasitism in the 14 fruit species was 3.03\%. When the parasitism was calculated individually for the 14 fruit species, the indices ranged from $0.07 \%$ to $14.37 \%$. The highest level was found in tangerine araçá (Psidium sp.), sugarapple and orange, in decreasing order. In Guatemala, the combined percentage of parasitism of Anastrepha spp. and $C$. capitata varied from 0.04 to $7.85 \%$, in 14 sampled species of fruits (ESKAFI 1990).

The fruits of C. reticulata (tangerine) and of Solanum 
Table I. Infestation indices of frugivorous larvae (Diptera: Tephritidae and Lonchaeidae) and their association with parasitoids (Hymenoptera) in 14 host plants sampled from the Cerrado of Mato Grosso do Sul, Brazil (January 1993 to March 1997)

\begin{tabular}{|c|c|c|c|c|c|c|c|c|c|c|}
\hline \multirow{2}{*}{$\begin{array}{l}\text { Host Fruits } \\
\text { n (kg) }\end{array}$} & \multirow{2}{*}{$\begin{array}{c}\text { Sites } \\
\text { (samples) }\end{array}$} & \multirow{2}{*}{$\begin{array}{l}\text { Index } \\
\text { Larvae/ } \\
\text { fruit }(\mathrm{n})\end{array}$} & \multirow{2}{*}{$\begin{array}{l}\text { Index } \\
\text { Larva/kg } \\
\text { of fruit }\end{array}$} & \multirow{2}{*}{$\begin{array}{l}3^{\text {rd }} \text { instar } \\
\text { recovered } \\
\text { larvae }(\mathrm{n})\end{array}$} & \multirow{2}{*}{$\begin{array}{l}\text { Taxa of } \\
\text { Frugivorous flies } \\
\text { (n) }\end{array}$} & \multicolumn{2}{|c|}{ Emerged flies } & \multirow{2}{*}{ Taxa of Parasitoids } & \multicolumn{2}{|c|}{$\begin{array}{l}\text { Parasitoids and } \\
\text { Parasitism }\end{array}$} \\
\hline & & & & & & $\mathrm{n}$ & Viability (\%) & & (n ) & $\%$ total \\
\hline $\begin{array}{l}\text { Anacardiaceae } \\
\text { Hog plum, } \\
\text { Spondias lutea } \mathrm{L} . \\
640(7,43)\end{array}$ & $\begin{array}{l}\text { Aquid. } \\
\text { (3) }\end{array}$ & 2.86 & 246.84 & 1,834Tephr. & $\begin{array}{l}\text { Tephritidae } \\
\text { Anastrepha } \mathrm{spp} . \\
\text { A. obliqua }(581)\end{array}$ & 1,145 & 63.54 & $\begin{array}{l}\text { Braconidae } \\
\text { Asobara anastrephae (1) } \\
\text { Doryctobracon areolatus }(3) \\
\text { Utetes anastrephae }(7) \\
\text { Pteromalidae } \\
\text { Spalangia gemina }(19) \\
\text { S. endius }(2)\end{array}$ & 21 & 1.74 \\
\hline \multirow[t]{2}{*}{$\begin{array}{l}\text { Red mombin, } \\
\text { S. purpurea L. } \\
484 \text { (6.88) }\end{array}$} & $\begin{array}{l}\text { Anast. } \\
\text { Aquid. } \\
\text { (8) }\end{array}$ & 1.18 & 83.43 & 570 Tephr. & $\begin{array}{l}\text { Tephritidae } \\
\text { Anastrepha spp. (226) } \\
\text { A. obliqua }(99) \\
\text { A. sororcula }(2) \\
\text { A. turpiniae }(1) \\
\text { Ceratitis capitata }(3)\end{array}$ & 229 & 40.17 & $\begin{array}{l}\text { Braconidae } \\
\text { A. anastrephae (1) } \\
\text { U. anastrephae (2) }\end{array}$ & 3 & 0.52 \\
\hline & & & & 4 Lonch. & $\begin{array}{l}\text { Lonchaeidae } \\
\text { Neosilba } \mathrm{sp} .(1) \\
\text { Dasiops sp. (1) }\end{array}$ & 2 & 50.00 & & & \\
\hline $\begin{array}{l}\text { Annonaceae } \\
\text { Sugar-apple, } \\
\text { Annona squamosa L. } \\
39 \text { (5.70) }\end{array}$ & $\begin{array}{l}\text { Anast. } \\
(4)\end{array}$ & 1.10 & 7.54 & 43 Lonch. & $\begin{array}{l}\text { Lonchaeidae } \\
\text { Neosilba } \mathrm{sp} \text {. }\end{array}$ & 41 & 95.35 & $\begin{array}{l}\text { Figitidae } \\
\text { Lopheucoila anastrephae (2) }\end{array}$ & 2 & 4.65 \\
\hline $\begin{array}{l}\text { Duguetia furfuraceae } \\
\text { St. Hil. } \\
204 \text { (11.46) }\end{array}$ & $\begin{array}{l}\text { Aquid. } \\
\text { Terenos } \\
\text { (8) }\end{array}$ & 1.15 & 20.42 & 234Lonch. & $\begin{array}{l}\text { Lonchaeidae } \\
\text { Neosilba } \mathrm{sp} \text {. }\end{array}$ & 200 & 85.47 & $\begin{array}{l}\text { Figitidae } \\
\text { Non-identified }\end{array}$ & 3 & 1.28 \\
\hline $\begin{array}{l}\text { Caryocaraceae } \\
\text { Caryocar brasiliense } \\
\text { Camb. } \\
562(77.25)\end{array}$ & $\begin{array}{l}\text { Aquid. } \\
\text { Rochedo } \\
(15)\end{array}$ & 7.06 & 51.35 & 1 Tephr. & $\begin{array}{l}\text { Tephritidae } \\
\text { A. sororcula (1) }\end{array}$ & 1 & 100.00 & & & \\
\hline & & & & 3,966 Lonch. & $\begin{array}{l}\text { Lonchaeidae } \\
\text { Neosilba sp. }\end{array}$ & 2,913 & 73.45 & $\begin{array}{l}\text { Figitidae } \\
\text { L. anastrephae (10) } \\
\text { Odontosema anastrephae (6) } \\
\text { Trybliographa infuscata (6) } \\
\text { Pteromalidae } \\
\text { S. gemina (2) }\end{array}$ & 22 & 0.07 \\
\hline \multirow[t]{2}{*}{$\begin{array}{l}\text { Combretaceae } \\
\text { Tropical almond, } \\
\text { Terminalia catappa } \text { L. } \\
443 \text { (15.32) }\end{array}$} & $\begin{array}{l}\text { Aquid. } \\
(10)\end{array}$ & 6.23 & 180.16 & 2,595 Tephr. & $\begin{array}{l}\text { Tephritidae } \\
\text { Anastrepha } \text { spp. (3) } \\
\text { A. zenildae }(1) \\
\text { C. capitata }(2,131)\end{array}$ & 2,134 & 82.23 & & & \\
\hline & & & & 165 Lonch. & $\begin{array}{l}\text { Lonchaeidae } \\
\text { Neosilba sp. }\end{array}$ & 140 & 84.85 & & & \\
\hline $\begin{array}{l}\text { Euphorbiaceae } \\
\text { Cassava fruits, } \\
\text { Manihot esculenta } \\
\text { Crantz } \\
1,760(4.12)\end{array}$ & $\begin{array}{l}\text { Faz. } \\
\text { Ranchinho, } \\
\text { Rochedo } \\
\text { (4) }\end{array}$ & 0.36 & 154.85 & 638 Tephr. & $\begin{array}{l}\text { Tephritidae } \\
\text { Anastrepha spp. } \\
\text { A. montei }(76) \\
\text { A. pickeli }(1)\end{array}$ & 140 & 21.94 & $\begin{array}{l}\text { Braconidae } \\
\text { Doryctobracon fluminensis } \\
\text { (12) }\end{array}$ & 12 & 1.88 \\
\hline \multirow[t]{2}{*}{$\begin{array}{l}\text { Mimosaceae } \\
\text { Inga, Inga laurina } \\
\text { (Sw.) } \\
1,545(11.43)\end{array}$} & $\begin{array}{l}\text { Aquid. } \\
\text { (6) }\end{array}$ & 0.35 & 47.59 & 77 Tephr. & $\begin{array}{l}\text { Tephritidae } \\
C \text {. capitata }\end{array}$ & 50 & 64.93 & $\begin{array}{l}\text { Braconidae } \\
\text { Non-identified (1) }\end{array}$ & 1 & 0.18 \\
\hline & & & & 467 Lonch. & $\begin{array}{l}\text { Lonchaeidae } \\
\text { Neosilba } \text { spp. }\end{array}$ & 199 & 42.61 & & & \\
\hline $\begin{array}{l}\text { Myrtaceae } \\
\text { Araça, Psidium sp. } \\
1,313(10.38)\end{array}$ & $\begin{array}{l}\text { Aquid. } \\
\text { (5) }\end{array}$ & 0.60 & 76.01 & 789 Tephr. & $\begin{array}{l}\text { Tephritidae } \\
\text { Anastrepha } \mathrm{spp} . \\
\text { A. sororcula }(167) \\
\text { A. striata }(79) \\
\text { A. fraterculus (3) }\end{array}$ & 517 & 65.53 & $\begin{array}{l}\text { Braconidae } \\
\text { D. areolatus (63) } \\
\text { Opius bellus (4) }\end{array}$ & 67 & 8.49 \\
\hline
\end{tabular}


Table I. Cont.

\begin{tabular}{|c|c|c|c|c|c|c|c|c|c|c|}
\hline \multirow{2}{*}{$\begin{array}{l}\text { Host Fruits } \\
\text { n (kg) }\end{array}$} & \multirow{2}{*}{$\begin{array}{c}\text { Sites } \\
\text { (samples) }\end{array}$} & \multirow{2}{*}{$\begin{array}{l}\text { Index } \\
\text { Larvae/ } \\
\text { fruit }(\mathrm{n})\end{array}$} & \multirow{2}{*}{$\begin{array}{l}\text { Index } \\
\text { Larva } / \mathrm{kg} \\
\text { of fruit }\end{array}$} & \multirow{2}{*}{$\begin{array}{l}3^{\text {rd }} \text { instar } \\
\text { recovered } \\
\text { larvae }(n)\end{array}$} & \multirow{2}{*}{$\begin{array}{l}\text { Taxa of } \\
\text { Frugivorous flies } \\
\text { (n) }\end{array}$} & \multicolumn{2}{|c|}{ Emerged flies } & \multirow{2}{*}{ Taxa of Parasitoids } & \multicolumn{2}{|c|}{$\begin{array}{l}\text { Parasitoids and } \\
\text { Parasitism }\end{array}$} \\
\hline & & & & & & $\mathrm{n}$ & Viability (\%) & & (n ) & $\%$ total \\
\hline \multirow{11}{*}{$\begin{array}{l}\text { Guava, } \\
\text { Psidium guajava L. } \\
1,728 \text { (89.78) }\end{array}$} & \multirow{11}{*}{$\begin{array}{l}\text { Anast. } \\
\text { Aquid. } \\
\text { Terenos } \\
\text { (13) }\end{array}$} & \multirow[t]{11}{*}{2.53} & \multirow[t]{11}{*}{48.62} & 3,993 Tephr. & \multirow{9}{*}{$\begin{array}{l}\text { Tephritidae } \\
\text { Anastrepha spp. } \\
(2,494) \\
\text { A. sororcula }(994) \\
\text { A. turpiniae }(161) \\
\text { A. striata }(50) \\
\text { A. obliqua }(26) \\
\text { A. zenildae }(19) \\
\text { A. fraterculus }(9)\end{array}$} & 2,876 & 72.02 & Braconidae & 115 & 2.75 \\
\hline & & & & & & & & D. areolatus (93) & & \\
\hline & & & & & & & & $U$. anastrephae (12) & & \\
\hline & & & & & & & & O. bellus (6) & & \\
\hline & & & & & & & & A. anastrephae (3) & & \\
\hline & & & & & & & & Non-identified (1) & & \\
\hline & & & & & & & & & & \\
\hline & & & & & & & & & & \\
\hline & & & & & & & & & & \\
\hline & & & & & \multicolumn{3}{|l|}{ C. capitata (382) } & & & \\
\hline & & & & 372 Lonch. & $\begin{array}{l}\text { Lonchaeidae } \\
\text { Neosilba spp. }\end{array}$ & 292 & 78.49 & $\begin{array}{l}\text { Figitidae } \\
\text { L. anastrephae (5) }\end{array}$ & 5 & \\
\hline \multirow{6}{*}{$\begin{array}{l}\text { Guavira, } \\
\text { Campomanesia } \\
\text { sessiflora (Berg.) } \\
8,179 \text { (19.66) }\end{array}$} & \multirow{6}{*}{$\begin{array}{l}\text { Anast. } \\
\text { Aquid. } \\
\text { Rochedo } \\
\text { Terenos } \\
\text { (9) }\end{array}$} & \multirow{6}{*}{0.10} & \multirow{6}{*}{42.52} & & \multirow{5}{*}{$\begin{array}{l}\text { Tephritidae } \\
\text { Anastrepha spp. } \\
(286) \\
\text { A. sororcula }(141) \\
\text { A. zenildae }(4) \\
\text { A. obliqua }(1) \\
\text { C. capitata }(5)\end{array}$} & 291 & 40.87 & Braconidae & 16 & 1.91 \\
\hline & & & & 712 lephr. & & & & $\begin{array}{l}\text { D. areolatus (7) } \\
\text { O. bellus (7) }\end{array}$ & & \\
\hline & & & & & & & & $U$. anastrephae (2) & & \\
\hline & & & & & & & & & & \\
\hline & & & & & & & & & & \\
\hline & & & & 112 Lonch. & $\begin{array}{l}\text { Lonchaeidae } \\
\text { Neosilba } \mathrm{sp} \text {. }\end{array}$ & 72 & 64.28 & & & \\
\hline \multirow{8}{*}{$\begin{array}{l}\text { Rutaceae } \\
\text { Orange, } \\
\text { Citrus sinensis L. } \\
2,346(357.26)\end{array}$} & \multirow{8}{*}{$\begin{array}{l}\text { Anast. } \\
\text { Aquid. } \\
\text { Terenos } \\
(179)\end{array}$} & \multirow{8}{*}{2.43} & \multirow{8}{*}{15.95} & & & & & & & \\
\hline & & & & 89 Tephr. & \multirow{3}{*}{$\begin{array}{l}\text { Tephritidae } \\
\text { A. turpiniae }(2) \\
\text { C. capitata }(66)\end{array}$} & 68 & 76.40 & & & \\
\hline & & & & & & & & & & \\
\hline & & & & & & & & & & \\
\hline & & & & & Lonchaeidae & 3,360 & 60.97 & Figitidae & 194 & 3.40 \\
\hline & & & & 5,611 Lonch. & Neosilba $\mathrm{sp}$. & & & L. anastrephae (164) & & \\
\hline & & & & & & & & T. infuscata (18) & & \\
\hline & & & & & & & & A. nordlanderi (12) & & \\
\hline Tangerine, & Anast. & 2.65 & 16.43 & 355 Lonch. & Lonchaeidae & 213 & 60.00 & Figitidae & 51 & 14.37 \\
\hline Citrus reticulata (L.) & Aquid. & & & & Neosilba sp. & & & L. anastrephae (47) & & \\
\hline $134(21.60)$ & $\begin{array}{l}\text { Terenos } \\
\text { (14) }\end{array}$ & & & & & & & A. nordlanderi (4) & & \\
\hline Solanaceae & & & & & & & & & & \\
\hline $\begin{array}{l}\text { Solanum viarum Dun. } \\
789(10.39)\end{array}$ & $\begin{array}{l}\text { Aquid. } \\
\text { (5) }\end{array}$ & 0.37 & 27.81 & 289 Lonch. & $\begin{array}{l}\text { Lonchaeidae } \\
\text { Neosilba } \text { sp. }\end{array}$ & 246 & 85.12 & $\begin{array}{l}\text { Figitidae } \\
\text { L. anastrephae (2) }\end{array}$ & 2 & 0.69 \\
\hline TOTALS / MEANS & 4 sites & 2.07 & 72.82 & 11,298 Tephr. & Anastrepha 4,814 & 7,451 & $44.83 \% \mathrm{~T}$ & 225 Braconidae & 527 & 3.03 \\
\hline 14 plant species & $(283)$ & & & 11,246 Lonch & C. capitata 2,637 & Tephr. & & & & \\
\hline 20,166 fruits & & & & & & & & 23 Pteromalidae & & \\
\hline $648,66 \mathrm{~kg}$ of biomass & & & & & Neosilba & 7,678 & $55.76 \% \mathrm{~L}$ & & & \\
\hline & & & & & Dasiops & Lonch. & & 279 Figitidae & & \\
\hline
\end{tabular}

Anast. (Anastácio); Aquid. (Aquidauana); Tephr. and T (Tephritidae) and Lonch. and L (Lonchaeidae).

viarum Dun. (Solanaceae) were infested exclusively by Neosilba spp. In oranges, $98 \%$ of adult tephritoids that emerged also belonged to this genus and all recovered parasitoids in these hosts were Figitidae (Eucoilinae). This suggests a specificity of this parasitoid subfamily to the lonchaeids. The economic importance of Neosilba species (as Silba) in Citrus and in other fruit trees has been pointed out in other Brazilian regions (Malavasi \& Morgante 1980; Raga et al. 1996, 1997).

The mean of $3^{\text {rd }}$-instar larvae viability in the 14 host fruit species was $44.83 \%$ for Tephritidae and $55.76 \%$ for Lonchaeidae. Considering the number of $3^{\text {rd }}$-instar larvae per $\mathrm{kg}$ of fruit the highest infestation levels were: Spondias lutea, Terminalia catappa, Manihot esculenta, S. purpurea, Psidium sp. and Caryocar brasiliense, respectively. These results show a trend 
of higher infestation levels in lighter and smaller fruits (Table I), according to the same observations of MALAVASI \& Morgante (1980).

The tephritids colonized 10 host species, and the lonchaeids 11 among the 14 fruit species sampled. Anacardiaceae, Myrtaceae and Euphorbiaceae (cassava fruit) were infested mainly by tephritids, in which the infesting larvae were parasitized by braconids.

Terminalia catappa fruits were mainly attacked by $C$. capitata. This host plant is native to the Malay Peninsula (LiQuido et al. 1991) and C. capitata has become sucessfully adapted to Tropical almond, in other Brazilian regions (RoNCHITeles \& Silva 1996; Silva et al. 1998).

Acknowledgements. To José Zorandir Nogueira (in memoriam) and his wife, Dina Cândida Fajardo, for their friendship and incentive in the collecting of fruits at their farm, Fazenda Ranchinho, Rochedo, Mato Grosso do Sul; Dr. Valmir A. Costa, Instituto Biológico, Campinas, São Paulo, for the identification of the Pteromalidae species; IBAMA-Mato Grosso do Sul (Jacob Ronaldo Kuffner) and MAARA-Mato Grosso do Sul (Celso Luiz Antonialli) for the donation of two vehicles to the Universidade Federal de Mato Grosso do Sul for assisting the "Projeto Moscas Frugívoras" field work; Coordenadoria de Pesquisa, Pró-Reitoria de Pesquisa e Pós-Graduação, Universidade Federal de Mato Grosso do Sul for the constant support; Conselho Nacional de Desenvolvimento Científico e Tecnológico-CNPq for the grant (1992 to 1994, Process No. 301067-92-9) and Coordenação de Aperfeiçoamento de Pessoal de Nível Superior-CAPES for the scholarship to the first author (1995 to 1997); Ubirazilda Maria Resende, for helping in the identification of the plant species and Professor Elsbeth A. Flunker (WI, USA) for the final revision of the English version.

\section{REFERENCES}

Aguiar-Menezes, E. \& E. B. Menezes. 1997. Natural occurrence of parasitoids of Anastrepha spp. Schiner, 1868 (Diptera: Tephritidae) in different host plants, in Itaguai (RJ), Brazil. Biological Control $\mathbf{8}: 1-6$.

Canal, N. A. D.; R. A. Zucchi; N. M. Silva \& S. Silveira Neto. 1995. Análise faunística dos parasitóides (Hymenoptera, Braconidae) de Anastrepha spp. (Diptera, Tephritidae) em Manaus e Iranduba, Estado do Amazonas. Acta Amazonica 25(3/4): 235-246.

Costa Lima, A. da. 1938. Vespas parasitas de moscas de frutas (Hymenoptera: Braconidae). O Campo 9: 69-72.

Eskafi, F. M. 1990. Parasitism of fruit flies Ceratitis capitata and Anastrepha spp. (Diptera: Tephritidae) in Guatemala. Entomophaga 35(3): 355-362.

Gallardo, F. E.; N. B. Díaz \& M. A. Uchôa-Fernandes. 2000. A new species of Trybliographa (Hymenoptera: Figitidae: Eucoilinae) from Brazil associated with fruit infesting Lonchaeidae (Diptera). Revista de la Sociedad Entomologica Argentina 59(1-4):21-24.

Hernández-Ortiz, V.; R. Pérez-Alonso \& R. A. Wharton. 1994. Native parasitoids associated with the genus Anastrepha (Dip.: Tephritidae) in Los Tuxtlas, VeraCruz, Mexico. Entomophaga 39(2): 171-178.

JiRón, F. L. \& R. G. Mexzon. 1989. Parasitoid hymenopterans of Costa Rica: geografical distribution of the species associated with fruit flies (Diptera: Tephritidae). Entomophaga 34(1): 53-60.

Leonel JR., F. L.; R. A. Zucchi \& R. A. Wharton. 1995. Distribution and Tephritid hosts (Diptera) of braconid parasitoids (Hymenoptera) in Brazil. International Journal of Pest Management 41(4): 208213.

Leonel JR., F. L.; R. A. Zucchi \& N. A. D. Canal 1996. Parasitismo de moscas-das-frutas (Diptera: Tephritidae) por Braconidae (Hymenoptera) em duas localidades do Estado de São Paulo. Anais da Sociedade Entomológica do Brasil 25(2): 199-206.

Liquido, N. J.; L. A. Shinoda \& R. T. Cunningham. 1991. Host plants of the mediterranean fruit fly (Diptera: Tephritidae): an annotated world review. Entomological Society of América, Miscelaneous Publications 77, $52 \mathrm{p}$.

López, M.; M. Aluja \& J. Sivinski. 1999. Hymenopterous larval-pupal and pupal parasitoids of Anastrepha flies (Diptera: Tephritidae) in Mexico. Biological Control 15: 119-129.

Malavasi, A. \& J. S. Morgante. 1980. Biologia de "moscas-das-frutas" (Diptera, Tephritidae). II: Índices de infestação em diferentes hospedeiros e localidades. Revista Brasileira de Biologia 40(1): 17-24.

Nascimento, A. S.; A. L. M. Mesquita \& R. A. Zucchi. 1984. Parasitism of pupae of Anastrepha spp. (Dip., Tephritidae) by Doryctobracon areolatus (Szépligeti, 1911) (Hym., Braconidae) in Citrus and tropical fruits. Anais da Academia de Ciências do Estado de São Paulo 2: $239-246$.

Ovruski, S. M. \& P. Fidalgo. 1994. Use of parasitoids (Hym.) in the control of fruit flies (Dip.: Tephritidae) in Argentina: bibliographic review (1937-1991). IOBC / WPRS Bulletin 17(6): 84-92.

Raga, A.; M. F. Souza Filho; V. Arthur \& A. L. M. Martins. 1996. Avaliação da infestação de moscas-das-frutas em variedades de café (Coffea spp.). Arquivos do Instituto Biológico 63: 59-63.

Raga, A.; M. F. Souza Filho; V. Arthur; M. E. Sato; L. A. Machado \& A. Batista Filho. 1997. Observações sobre a incidência de moscas-dasfrutas (Diptera: Tephritidae) em frutos de laranja (Citrus sinensis). Arquivos do Instituto Biológico 64: 125-129.

Ronchi-Teles, B. \& N. M. da Silva. 1996. Primeiro registro de ocorrência da mosca-do-mediterrâneo, Ceratitis capitata (Wied.) (Diptera: Tephritidae) na Amazônia brasileira. Anais da Sociedade Entomológica do Brasil 25(3): 569-570.

Salles, L. A. B. 1996. Parasitismo de Anastrepha fraterculus (Wied.) (Diptera: Tephritidae) por Hymenoptera, na região de Pelotas, RS Pesquisa Agropecuária Brasileira 31(11): 769-774.

Silva, J. G.; K. Uramoto \& A. Malavasi. 1998. First report of Ceratitis capitata (Diptera: Tephritidae) in the Eastern Amazon, Pará, Brazil. Florida Entomologist 81: 574-577.

UchôA-Fernandes, M. A. \& R. A. Zucchi. 1999. Metodología de colecta de Tephritidae y Lonchaeidae (Diptera, Tephritoidea) y sus parasitoides (Hymenoptera). Anais da Sociedade Entomológica do Brasil 28(4): 601-610.

Wharton, R. A.; F. E. Gilstrap; R. H. Rhode; M. Fischel \& W. G. Hart. 1981. Hymenopterous egg-pupal and larval-pupal parasitoids of Ceratitis capitata and Anastrepha spp. [Dip.: Tephritidae] in Costa Rica. Entomophaga 26(3): 285-290.

Wharton, R. A.; S. M. Ovruski \& F. E. Gilstrap. 1998. Neotropical Eucoilidae (Cynipoidea) associated with fruit-infesting Tephritidae, with new records from Argentina, Bolivia and Costa Rica. Journal of Hymenoptera Research 7(1): 102-115. 